\title{
A Reinterpretation of the Relationship between the Architecture of Ancient Mataram Era Temples in Indonesia and of 7th-10th century Temples in South India
}

\author{
Rahadhian P Herwindo $^{1}{ }^{*}$, Basuki Dwisusanto $^{2}$, Indri $\mathrm{A}^{3}$ \\ ${ }^{123}$ Lecturer of Department of Architecture, Parahyangan Catholic University, Bandung, Indonesia.
}

\section{Abstract}

History shows the interaction between temple architecture in Indonesia and India, especially South India. This interaction is demonstrated by the entry of Hindu-Buddhism into Indonesia. However, local genius in Indonesia also plays an active role in responding to the entry of outside traditions, through the strength of local creativity. Hindu-Buddhist tradition basically follows the pattern of enriching the culture in Indonesia. At a glance, the form of temples architecture in Java and South India shows similarity, such as ornamental processing and sculpture techniques. However, this similarity must be studied architecturally as a construction technology perspective, so it is not merely a style or ornamentation. Therefore architectonic studies are used to properly assess its form. This research has been conducted with the qualitative approach, descriptive and argumentative methods, referencing historical records, and by way of typo-morphology (form and transformation). The research has been conducted into temple architecture in Indonesia dating back to the Ancient Mataram Era (7th-9th century AD) by drawing comparisons with temples in South India of the same era. The results of this study indicate that Indonesia used a different technique from South India in forming the inner roof cavity (tiered hollow ceiling) of the temple, which is the spatial arrangement technique, while in India a flat ceiling as a consequence of the post-and-lintel technique was used. In the 10th century the new stacking technique was used in South India. In Java itself this technique has been known since the early 7th century or even before that in the Classical Era. This technique then developed rapidly in the Middle Classical Era and allowed the temples to be bigger and taller like Prambanan, also supported by the connection technique between stones that made use of keys. Prambanan is
\end{abstract}

the first and tallest high-rise building in Southeast Asia, while in South India there were no large and tall temples like Prambanan in that particular era. Only in the 10th century did a tall building rear its head there, as can be verified in the Chola remains. Furthermore, it can be estimated that the architectural technique of stacking hollow ceiling in the great temples in South India in the 10th century might have been inspired by the construction of large temples on the island of Java at the end of the 8th-9th century.

Keywords: Architecture, India, Indonesia, Post-Lintel, Hollow Ceiling, Tectonic

\section{INTRODUCTION}

The Hindu-Buddhists who entered Indonesia with their traditions basically came from India [1]. Buildings related to Hindu and Buddhist traditions are directly or indirectly thought to have been influenced by Indian culture[2]. However, some theories explain that the relationship with India does not just directly correlate with the traditions of Indonesia, in other words there are also strong local elements compared to the Indian influence[3]. India has merely enriched the existing culture, instead of changing it to resemble the India model [4]. Local genius plays an important role in relation to the inclusion of traditions from India, including the architecture of temples in Indonesia [5]. Indonesia had basically been familiar with stone processing techniques because it had already passed through the Megalithic and Neolithic Ages. The tradition of processing stones and metals (Iron Age) had already become part and parcel of Indonesian culture before the inclusion of Indian culture [6].
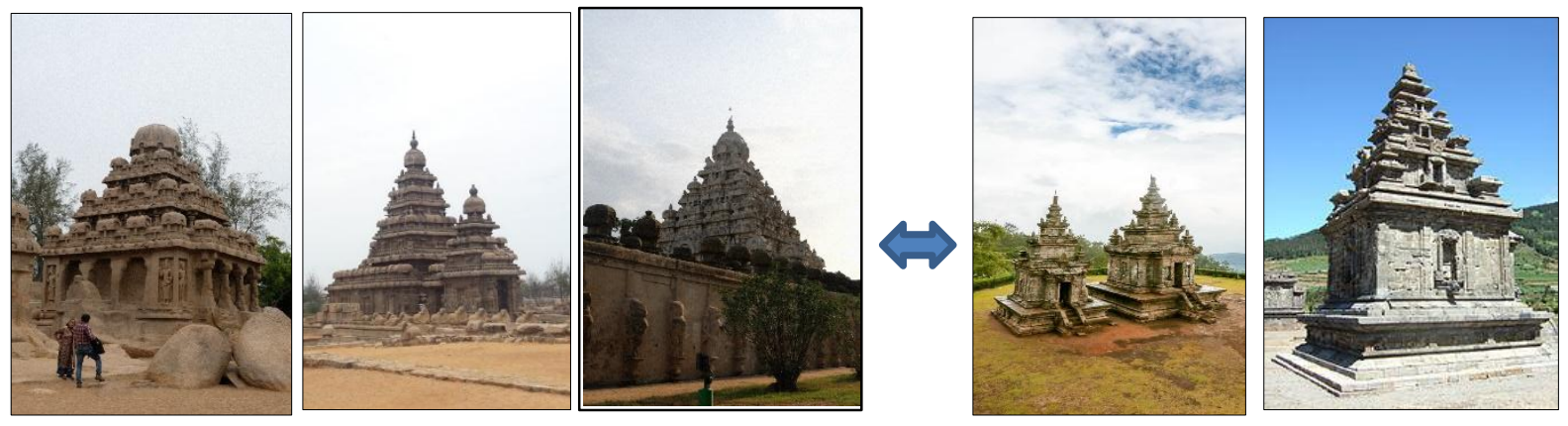

Fig. 01. Ancient South Indian Temple (left) and Ancient Javanese Temple (right) [6]. 
At first glance the form of architecture in the ancient Mataram and South India shows the appearance, especially from the processing of ornaments and sculpture techniques [7]. However, it can be discerned clearly that there are significant differences in the processing of the inner ceiling. Based on the architectural approach the difference in processing the roof cavity is an important matter related to its construction technology. This study aims to further recognize that the relation of Javanese temples and those in South India as observed in the temples of the early to Middle period is based on its architectural aspects in relation to its form. Previous studies [8] have shown the influence of Javanese temples in Cambodia-Angkor. In this study, it is possible to have a reverse flow to India, as in the 9th century, considering the Nalanda Inscription (an ancient Buddhist inscription located in Nalanda, within the present day Bihar state of Northeastern India that has been dated to $860 \mathrm{CE}$ ). The inscription talks about King Dewapaladewa of Bengala (Pala Empire) who had granted the request of Sri Maharaja of Suvarnadvipa, Balaputra, to build a Buddhist monastery at Nalanda, and shows the royal friendship between Balaputradewa (the Maharaja of Srivijaya in the 9th century CE as well as the former head of the Sailendra dynasty) and Dewapaladewa, marked by the construction of a temple initiated by Balaputradewa in the Bengal region.

Comparative studies conducted are using the architectonic approach because in general the study of Javanese and Indian temple relations is only related to style with ornamentation as a starting point [9]. Understanding the term "architectonic" according to some international dictionaries (Oxford, and other sources) among others, is (adj) (1). of or relating to architecture or design. (2) Having qualities, such as design and structure, that are characteristic of architecture as a work of art forming an architectonic whole (3) Philosophy of or relating to the scientific systematization of knowledge. Meanwhile in Latin, architectonic means to deal with, or in accordance with the principles of architecture. Architecture in Greek is architectonic, derived from architectonic, meaning organized and has an integrated structure that suggests an architectural design (disimplivity.blogspot.com/ 2010/01/arsitektonik.htm).

Therefore what is meant by understanding architecture in this study is related to the characteristics / principles of architecture or design such as the problem of form-space including its forming tectonics. The latter concerns the relationship between forms and their constituent structural elements. Structural elements can simultaneously be architectural elements that provide architectural value.

Etymologically the word 'tectonic' is derived from the ancient Greek noun 'tecton' which means carpenter or builder, while in the Sanskrit language the term Taksan is also known which means craftsman carpentry and matters relating to the use of axes. In conclusion from the etymology of the language, this word is often synthesized from architecton or master builder. In its development, this word not only refers to technical matters but to be more exact, poetic elements derived from the art of the building craft itself. According to Adolf Heinrich Borbein [10], the word tectonics refers more to aspects of art in construction techniques than aspects referring to the usefulness of an item. With the passage of time, the meaning of the word tectonic in construction tends to create works of art, depending on whether or not the application of the level of usefulness of the art is applied. Tectonics can be summed up as the 'art' value of the construction itself. The process of construction and the results of these processes create micro and macro values in a building. Continuity between technologies, construction processes, structures and details in buildings will create a good and high-value tectonics.

\section{METHOD}

This research has been conducted by employing the qualitative approach, in a descriptive and argumentative manner, referencing historical records, and through the typomorphological [11] [12] approach (referring to shape and transformation). The research has been conducted into temple architecture in Indonesia in the Mataram Era of the 7th-9th century by conducting comparative studies with temples in South India in the same era. The study focuses on the phenomena / theories / concepts that underlie each of these buildings, for example in relation to aspects of their form and tectonics. The descriptive approach is used to explain the design holistically. The argumentative approach has been employed to explain their inter-relationship. Therefore a historical study [13] is needed to be able to explain the comparison between temples in South India and Indonesia. Based on the comparison between the Javanese and South Indian both, the relation between them is expected to be recognized

\section{RESULT AND DISCUSSION}

The study of the relationship between both in India and Java in the Ancient Mataram era can be explained through tectonic aspects in relation to the shape of the building in addition to relating to spatial planning and mass. In general [14], temple building in both India and Indonesia has a building base element under which there is a foundation to support the building. Above the base of the building there is a room with walls surrounding it, and this part can be called the building body. At the top of the building there is the roof of the building in the form of a triangular / pyramidal prism silhouette centering to the middle This roof is divided in a hierarchical manner, that is to say, the higher, the smaller. In tectonic distribution the style does show that the more upward it goes, the smaller it becomes. The tectonic distribution of the force does indicate that going upward means getting smaller, given the weight of the material used.

In Chapter XVIII, sections 93 - 99, Mānasāra [15] is aware of three specific styles, each of which has the different structural features of Nagari (north), Vesara (east), and Drāvid a (south). In contemporary literature [16], Nāgari and Drāviḍ a are the styles with the clearest architectural definition and anatomy so that they are generally juxtaposed with each other to show the different architectural traditions of north and south India. Vesara is a mixed style characterized by Nāgari and Drāviḍ a, but generally with unclear definitions.

Hindu temple buildings have various specific parts that 
contribute to the overall shape of the temple building. Based on an analysis of various Vāstu books, Kramrisch [17] states that Indian Hindu temples can always be divided into six to seven basic parts of Adhis ț hāna (Umpak, with or without the Upapīt ha or base), Pada (pillars or walls), Prastara, Gala, Śikhara and Stūpi. Vāstuśāstra has an extensive vocabulary to describe and describe each part of the building of Hindu temples. However, since the various Vāstuśāstra are arranged at different times in different regions of India, some parts of public buildings have alternative names and descriptions that differ slightly from one another. It is also possible that the exact names in the two books refer to two unrelated features or elements, therefore the naming of each part needs to pay close attention to the source of the name used.

EachVāstuśāstra agrees with the concept of spatial division that should be used as the basis for any building design; this concept is known as Vāstu Puruṣ a Mạ̣ ḍ ala. Vāstu is an architectural concept that concerns the ideal form, purpose, and design theme on a site. Purus a refers to the spirit of a site that mediates Vāstu in the physical design of the building to be constructed. Man dala is the mechanism of applying vāstu purus a that can be contained in the form of drawings, diagrams and geometric patterns as symbolic representations of the universe. In its original use, vāstu puruṣ a maṇ ḍala is a conceptual foundation that is not intended to be a geometrical blueprint, as emphasized by Chakrabati [18]. For all its textual perfection, Man d ala can only be achieved with a flat "footprint"/site and without features that are difficult to find in reality. Therefore, the vāstu purus a man dala serves as a conceptual guide and ideal scheme that needs to be adjusted with various other considerations in their application in the field.

At first glance the building figures between the both in Java and in South India show a similarity, but when compared in greater depth they show a significant difference, especially in terms of the tectonic arrangement. According to Hardy [19] the early Indian temples were built by carving stone hills into caves. This can be seen in several places at Ajanta. This cave is formed in the form of spaces with interior processing resembling wooden buildings that have columns. In this sculpting building technique, the columns are not really needed because after all, it is a cave. These columns are formed representing a building that has columns. The stone carving technique came to be known as Rock cut or scraping. In addition to stone carving, there are various temples carved from free-standing monolith stones such as the ones found in Pancaratha and Ellora.
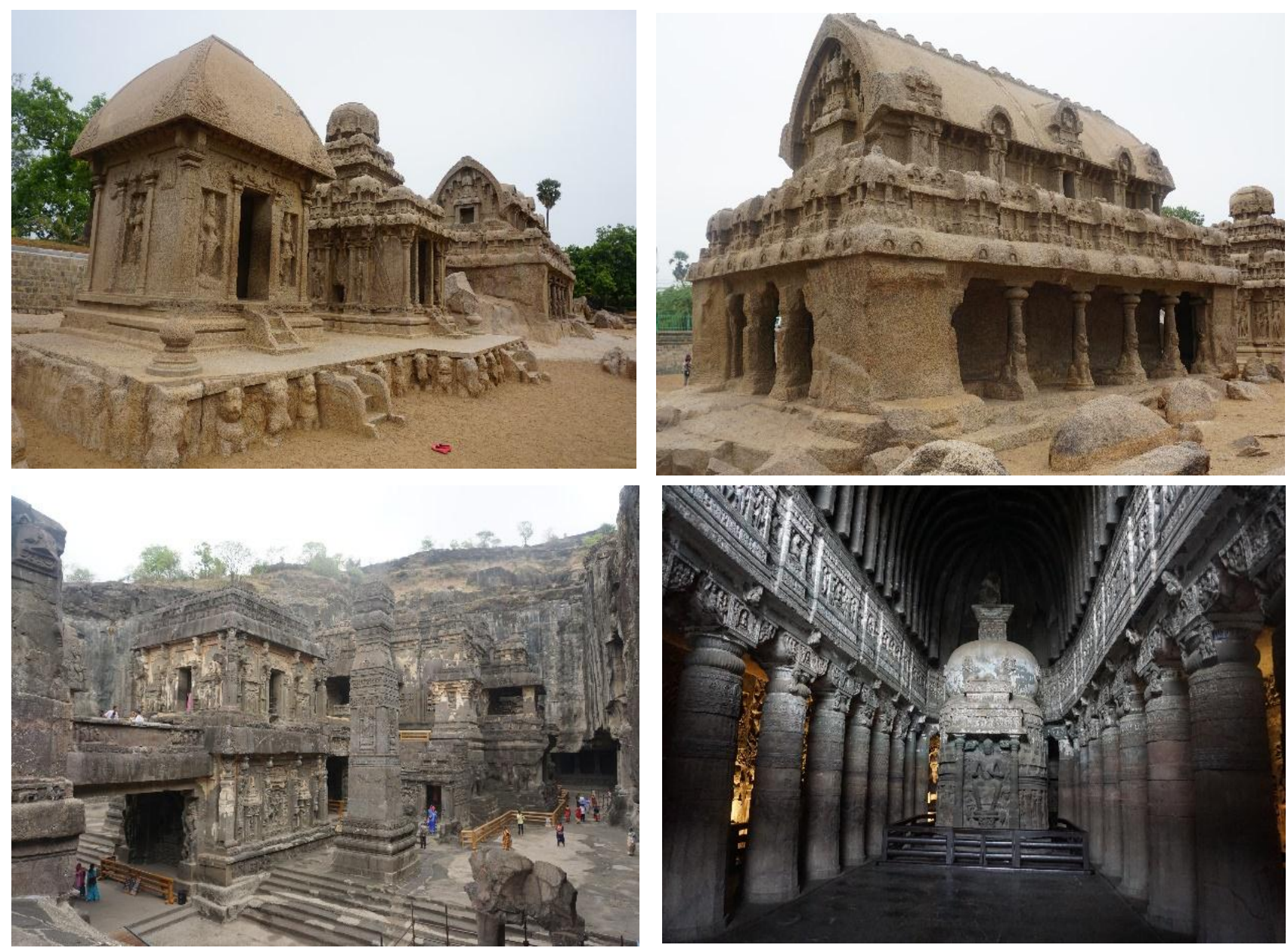

Fig. 02. Pancaratha (top) Elora dan Ajanta (below) = Monolith temple [6] 


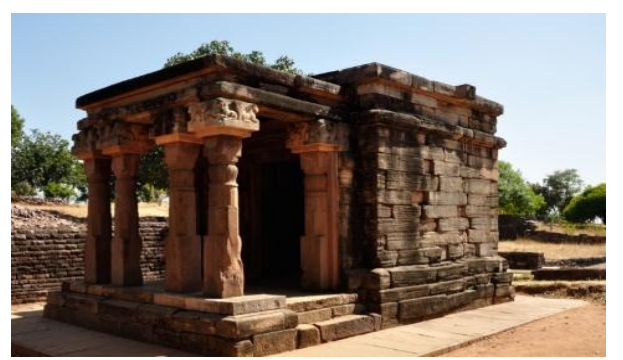

Fig. 03. Ancient temple-post and lintel, Kailasanthar the first and next development - stone stacking techniques (main temple and mandapa ) [6]
In the next phase the building of the temple shows the development of the tectonics which is not only in the form of carved monolith buildings such as these caves but in the form of buildings that stand freely with stone stacking techniques. The stones are cut and then arranged in a cyclopean manner (the kind of masonry used in ancient Greek architecture, characterized by massive dry undressed blocks of stone) to form walls and roofs and then carved. The temples in South India that use this stacking technique make an impression of having been very strongly influenced by the tectonic arrangement of the post-and-lintel style (relating to a system of architectural construction based on vertical supports and horizontal beams as distinguished from systems based on arches or vaults) as developed [20] by Ancient Greek Architecture. This technique makes buildings featuring a flat ceiling instead of allocating space to rooms. By looking at these developments in a nutshell it can be seen that temples in India were originally built by carving hills instead of starting with stone. This technique subsequently developed into a Post-andLintel Technique such as the one found in Ancient Greece in the above-mentioned cyclopean style compiled walls such as the Shore temple and Kailasanathar Kancipuram. This is evident in the main building and the mandapa (pavilion).

In the main building and the mandapa, a flat stone structure is placed on top of the massive wall and columns. In the main building on a flat stone, then the stones are stacked more and arranged increasingly upward, getting smaller toward the top. Inside the interior, it looks like a flat building ceiling, keeping in mind that there is a stone structure on it. The composition of these stones form a pyramid cone up. Since the system is Postand-Lintel with heavy stones, the walls of the main building are quite thick. Around it, the construction is also strengthened by a perimeter fence wall. Tectonically, this building shows a pileup concept employing the post-and-lintel technique, with a flat ceiling. It is also recognized in the ceiling of caves in Ajanta and Ellora or in their free-standing temples such as the ones found in Pancaratha and the Shore Temple.

Now this is where the point of difference lies with Indonesia, although temples in Indonesia are arranged without columns but instead use bearing walls like those in South India, though not as thick, relatively speaking. The construction of old temples in Indonesia, especially on the island of Java at that time was based on familiarity with the structure of a hollow roof / stacked ceiling composed of stones in four directions and at closed at the top with keystone. This type of stone is also known as cupola stone that serves to break the roof load. This keystone is reminiscent of the Roman arch but as a matter of fact it differs in certain respects. The technique of stacking the inner roof of the old both in Indonesia meets at one point and is locked with a stone (batu cungkup). Through this batu cungkup, force is channeled to the four sides of the temple that are supported by the bearer walls in all four directions. This system resembles the flow of force on the arches or domes like the ones encountered in Rome. Even in some temples there are curved arrangements on the interior of the roof. With this technique, it allows the hollow-ceilinged temple space to step into a point, which is different from India.
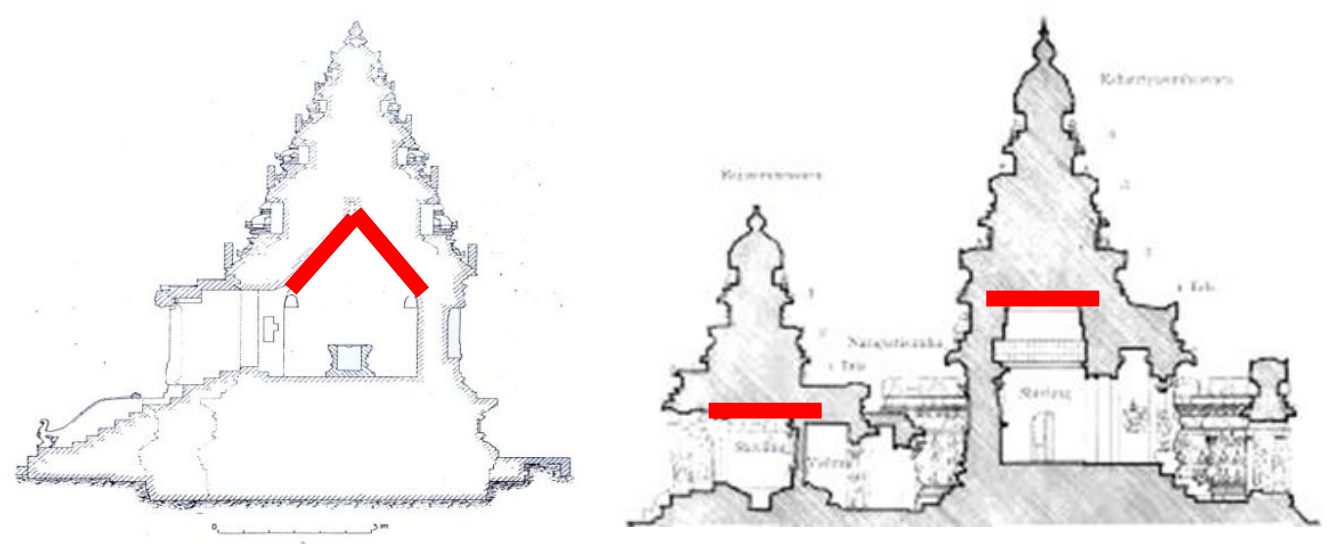

Fig.04. Comparison Ancient Javanese temple 7 CE (Arjuna) and South Indian Temple 7 CE (Shore) [6] [21] 

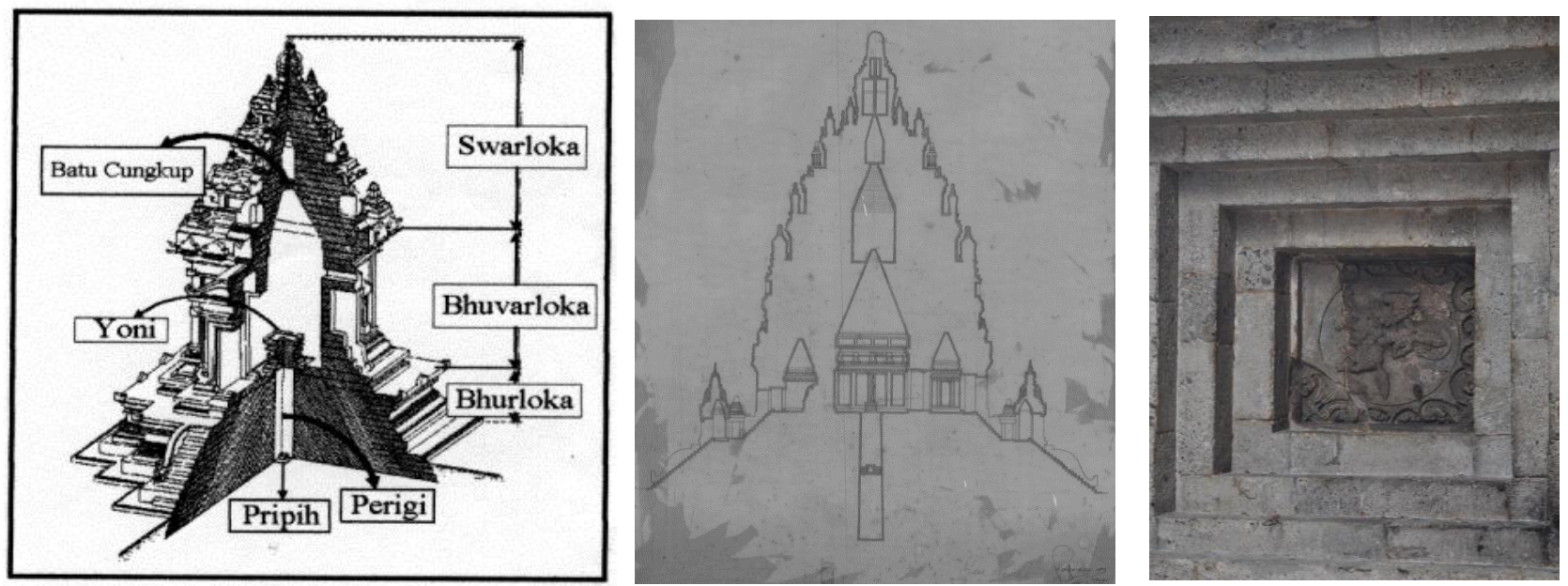

Fig.05. Batu Cungkup [6]

Compared to South India, the age of the temple in Indonesia with the hollow space/cavity stacking technique is relatively older, namely Arjuna (650 AD) from temples that use post-andlintel techniques such as the Shore temple and Kailasantha Kanciphuran in South India going back to $\pm 680 / 700$ AD. The Arjuna temple is estimated to be younger than the cave-shaped temples of India. The point of difference can be clearly shown, namely that in India the ceilings of buildings are flat while in Indonesia there are cavities forming terraces, making them look like tall or high-rise buildings. These hollow spaces or cavities in Javanese Hindu Temple usually consist of two at the top, which for philosophical and functional structural reasons serve to reduce the weight of the roof, considering that Indonesia is often hit by earthquakes.

Philosophically, the uppermost roof cavity functions as a place where the deity dwells when descending to Earth before entering the phallic-shaped lingga or statue below. The existence of a cavity with a tectonic arrangement like this shows that the temples in Indonesia are free from the influence of South Indian tectonics because they are different. This tectonic can be estimated to have come from the creativity of the Indonesian people themselves, because in South India as the origin of Hindu buildings there has not been found a system as recognized in the Old temples in Indonesia in the 6th-7th centuries. Indonesia has not used a post-and- lintel system for its temple buildings. Cavity stacking techniques like this are used in all temples in Indonesia until the Prambanan period as its climax and Majapahit as the closing seal on the HinduBuddhist era in Indonesia.

According to Atmadi [22] the roof of the temple always consists of a tier arrangement (generally three levels with one crown top) that becomes smaller and higher, ending with a crown. This crown can be a phallic-shaped lingga / amalaka / shikara, stupa / genta (Sewu), ratna (Prambanan), or take the shape of a cube (as found in Temples in East Java). The roof of the temple is symbolized as a Swahloka or a dwelling-place for the gods/deities. On the roof of Hindu temples there is a small cavity which is essentially a rectangular stone carved with a particular image, known as a cungkup stone which functions like key stone. Prambanan has more than one roof cavity.
According to Soekmono [14] the cavity was intended as a temporary abode for the gods/deities. From a technical point of view of manufacture, the cavity is used to reduce the roof pressure load which must be supported by the body wall of the temple, as well as a vertical central load breaking and channeling to the sideways compressive force. Therefore the cungkup stone is known as a load-dosing stone. The loadbearing cungkup stone is actually nothing but the development of a fundamental structural theory, namely the distribution of force from a centralized load. The weight of the roof is channeled through the sloping ceiling towards the walls of the temple.

According to Soekmono [14] the results of research on the Merak Temple in Central Java show other uses of the cavity or hollow space. The base of the cavity is the same shape and result of the same workmanship as a coffin, so that it can be concluded that the cavity has a strong religious function as the place where the gods/deities dwell before penetrating and animating the statue of the embodiment that is right below it. The cungkup stone is usually decorated with a red lotus flower symbolized as a god's throne and perforated petals depict a place for storing various objects belonging to the god. This symbolization reinforces the notion of a direct correlation between the cavity and the temple chamber. This shows that in Hindu temples, the making of the cavity has two important functions, namely supporting the function of the construction structure, namely lightening the roof load and serving a symbolic function. In this Buddhist temple, the cavity also forms the conical ceiling of the temple.

The contribution of the spatial structure structure is that in the Central Classical era, it was developed in a more sophisticated way leading to the emergence of the construction of large temples such as the Kalasan Temple, Sewu Temple and the largest of them all, Prambanan. The latter is considered to be large and tall because the builders of that era were able to use that new-found hollow stacking technique. It is simply not possible to build a temple like Prambanan without having a reliable architectural tradition that was demonstrated during the time of the ancient temples such as Dieng, Gedongsongo. Prambanan is the first tallest Hindu temple in the world ever 

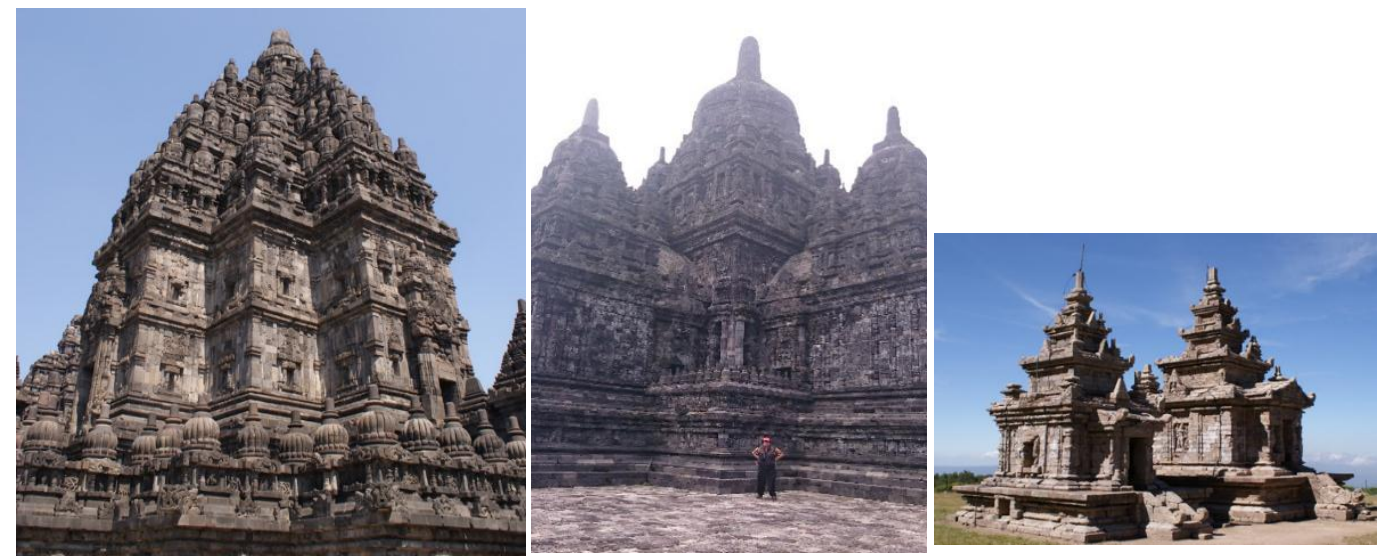

Fig.06. Prambanan, Sewu, dan Gedong Songo [23]

built by humans. Previous studies have shown that the Angkorian both were heavily influenced by Prambanan.

This research shows that not only Cambodia was inspired by this Javanese both, but India as well, as the origin of Hindu buildings. Buildings in South India dating back to the 10th-11th century were estimated to have been inspired using deep space stacking techniques such as the ones employed in Indonesia for Prambanan, considering that before the latter was built in Indonesia, in there was no visible construction of large and tall temples like Prambanan to be found in South India.

This indicates that the tectonic science of compiling Javanese stones is thought to have inspired the construction of temples in India after the 9th century, such as the ones found in Tanjore and Madurai [6]. Large temples were almost simultaneously erected in the 9th century on Java such as Borobudur-MendutNgawen in the North and Prambanan, Kalasan, Sewu, Bubrah, Sojiwan Lumbung and others, while in South India these largesized temples were not known in that century, at least none that could bear comparison to the ones built on the island of Java.

The management of large-scale projects such as the construction of large-sized temples in this era should have been supported by an adequate project managerial system as well. The construction of large temples, taking place at almost the same time, indicates that hundreds of human workers must have had sufficient building skills, both related to aspects of design planning, and to the implementation of the construction. This must have enable residents living in this era that were familiar with building expertise as highly skilled builders to make their main living at these projects.

Thus the tectonic processing [6] of figures and construction shows that Indonesia had actually discovered and used its own technology that is differed markedly from South India. The spatial roof stacking technology was further developed until large and tall buildings such as Prambanan could be constructed. This technology was not only used on Java alone at the time, but was also developed at another place. The phenomenon shows that Indonesian people have been able to bring advanced construction technology in their time and are able to inspire other places. This technology held out until the end of the Hinduization era and its footprints were further recognized in the tumpang sari-Joglo buildings on the island of Java.

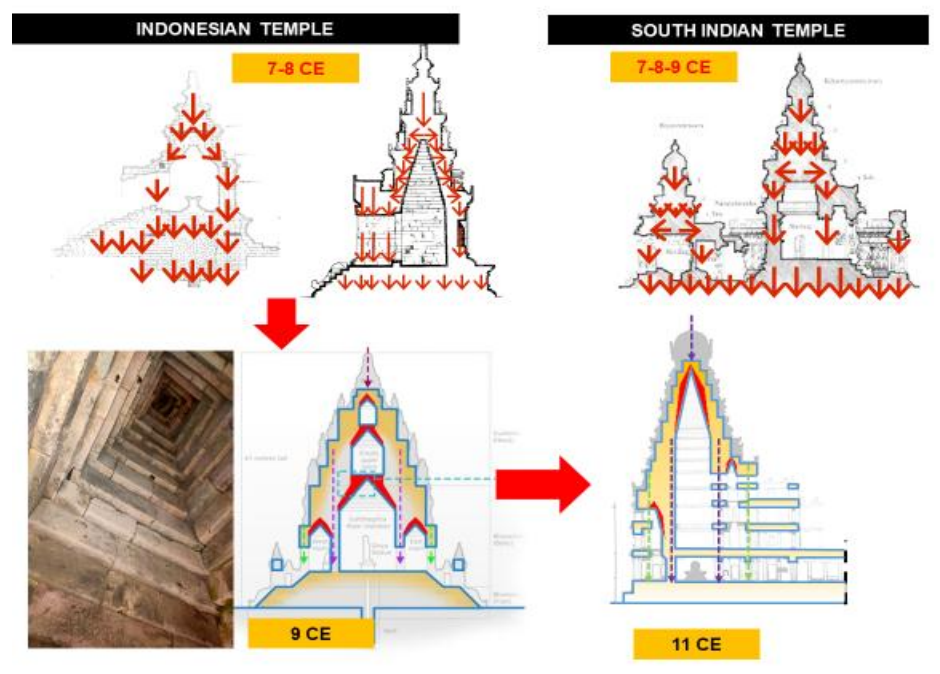

Fig.07. Relationship Javanese temple and South Indian temple [6] [21] 


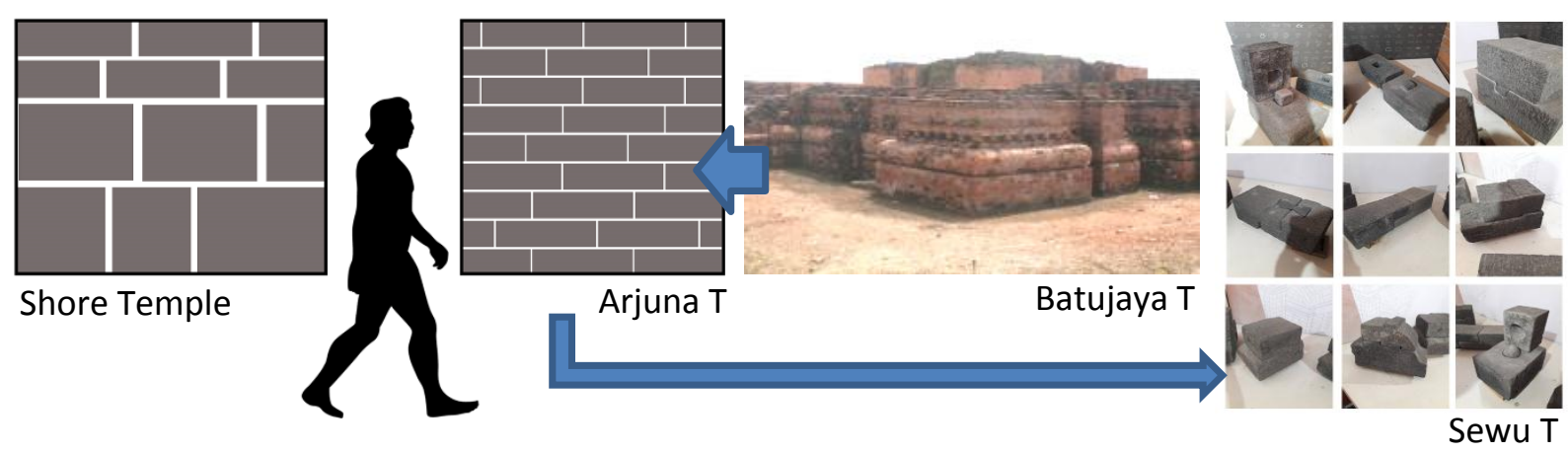

Fig.08. Comparison the development Javanese temple and South Indian temple [6][24]

The material used for Javanese temples is generally made of hard andesite, so we need reliable carpentry tools for processing it, while in South India softer stones were used. The ability to make reliable metal tools is also shown in Indonesian traditions, especially for cutting hard stones. Temples in Indonesia use stone material that is cut into pieces such as brick material, which has a small dimension compared to the enshrinements in South India. Cutting stones into smaller and the same size requires adequate skills and tools. Apart from the dimensions of the use of small pieces of stone, this phenomenon can be attributed to old both like those in Batujaya made of bricks.

Dieng's temples (estimated to be younger than Batujaya) is estimated to be inspired by the technique of compiling material derived from brick, although the material is made of stone, and of course the technique of arranging bricks and stones is different, bearing in mind that bricks are more easily damaged or destroyed. At this time, it is estimated that there has been a transformation in the use of brick to stone, in addition to wood to stone in the context of the baths in the Old Classical era. The temples in Java before the Dieng era are estimated to have used wooden materials in addition to brick, as can be discerned in the Batujaya both of the 2nd-4th century AD.
Based on the restoration of several temples in Dieng, there is no technique of locking between stones except with a thin layer of certain material used to glue between bricks. In both made earlier the connection technique has been identified by interlocking which makes the connection between stones more stable and unchanged.

The connection between the stones makes the building more stable and makes it possible to enlarge the dimensions of the figure, such as the Prambanan complex, Sewu, and others. This inter-stone key technique is the development of ordinary stacking techniques such as the ones employed at Dieng, which is bound to be very useful at a later stage for buildings with large dimensions in response to lateral forces due to earthquakes.

This inter-stone key technique allows the arrangement of space to be wider than the temples of the Old Classical era, as well as the roof space or spatial ceiling. This stone connection technique was not well known in the old Indian both, as it was not until the 10th century that it became known as the Brihadisvara both, after the construction of large temples in Java.
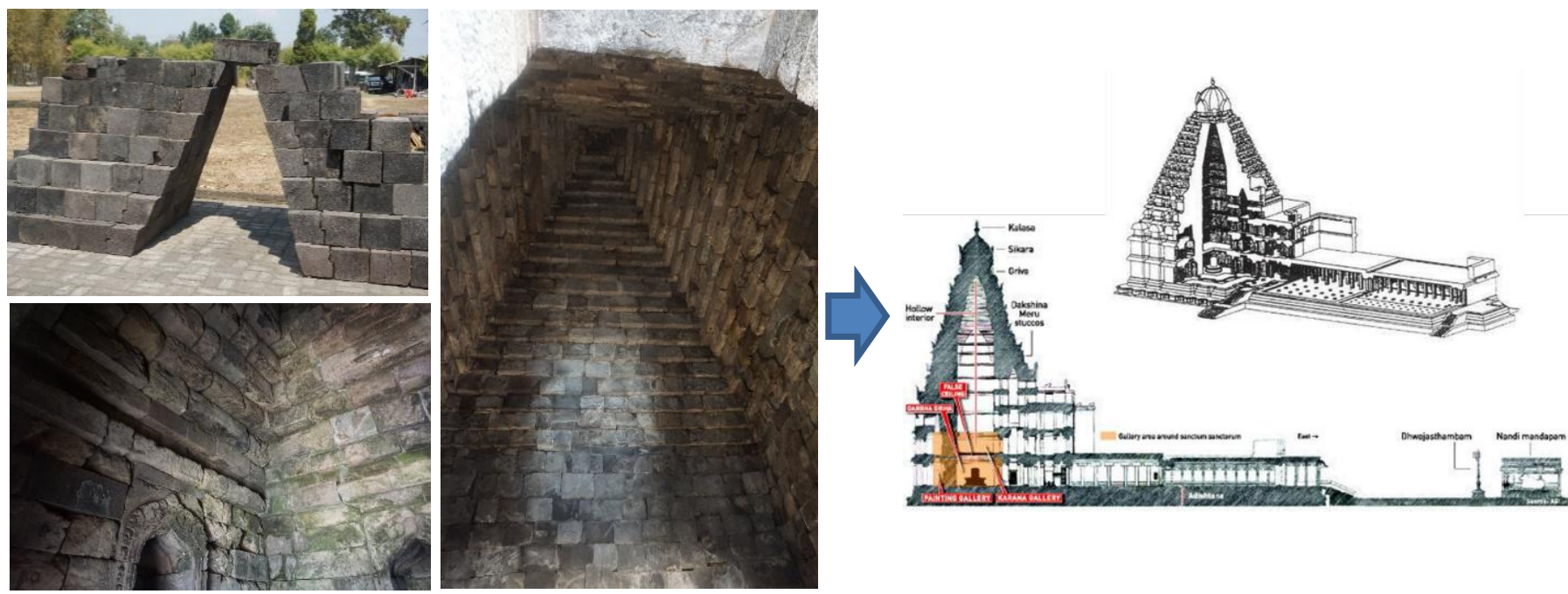

Fig.09. Architectonic Javanese temple 7-9 CE and South Indian temple 11 CE. [6] [21] 


\section{CONCLUSION}

In the past, the ancestors of the Indonesian people learned that carving techniques indeed originated from India. This can be compared to the results of the two places that show similarities, although on the other hand in Indonesia there has been a Megalithic era which is closely related to stone processing and an older era namely Neolithic that is closely related to metal processing. Without the knowledge of metal processing, it is certain that it will be difficult to create metal chisels to process hard stones like andesite. However, in the context of technology, architecture arranges the stone into a complete temple building, Indonesia has a different technique from South India, especially in forming roof cavities, with the technique of stacking rooms, while in India a flat ceiling was used as a consequence of the post-and-lintel technique. It was only in the 10th century that new cavity stacking techniques were used in South India, which is identical to Java. In Java itself this technique had already been known since the early 7 th century or even before that, in the Old Classical era. This technique then developed rapidly in the Middle Classical era and reached its peak when Prambanan was built. Prambanan is the first tallest building in Southeast Asia. In addition, in the era of the Prambanan and Borobudur Temples, the construction technique of the connection between the stone and certain keys that support the building to be made larger and taller was known.

In South India there were no large and tall temples in this particular era, as it was not until the 10th century that high buildings were recognized in the remains of the Chola. By looking at the phenomena above it can be estimated that the architecture of large temples in India cannot be ruled out to have been influenced by Javanese tradition, especially starting in the 10th century considering that on the island of Java many large temple buildings had been built at the end of the 8th-9th century. This can indicate the existence of backflow from Indonesia to India. On the other hand, relations with India were actually quite close, as demonstrated in the 9th century by Balaputradewa, King of Sriwijaya in the Ancient Mataram Era.

\section{Acknowledgment}

- Indonesian Education and Culture Ministry - HIKOM RISTEKDIKTI, BPCB Jawa Tengah-Yogyakarta, Jawa Timur, Balai Arkeologi Yogyakarta

- Institute for Research and Community Services, Parahyangan Catholic University - LPPM UNPAR

- Department of Architecture, Parahyangan Catholic University, Indonesia

\section{REFERENCES}

[1] Chihara, daigorō (1996) Hindu-Buddhist Architecture in Southeast Asia, EJ Brill. ISBN 9784306041400

[2] Romain, julie (2011) "Indian Architecture in the 'Sanskrit Cosmopolis': The Temples of Dieng Plateau", Early Interactions between South and Southeast Asia: reflections on cross-cultural exchange, Institute of Southeast Asian Studies. ISBN 9789814345101

[3] Degroot, véronique myriam yvonne (2009) Candi Space and Landscape: A Study on the Distribution, Orientation and Spatial Organization of Central Javanese Temple Remains, Leiden University.

[4] Santiko, Hariani (1995), Seni Bangunan Sakral Masa Hindu-Buda di Indonesia Analisis Arsitektur dan Makna Simbolik, Pidato Pengukuhan Guru Besar Madya Tetap pada Fakultas Sastra Universitas Indonesia, Depok.

[5] Miksic, John; Tjahjono, Gunawan (2002) Indonesian Heritage Vol VI: Arsitektur, Grolier International. ISBN 9813018305

[6] Herwindo, Rahadhian P (2019) Membangun identitas indonesia melalui penggalian keunggulan seni-budaya arsitektonik nusantara dalam tantangan globalisasi Laporan Penelitian Ristekdikti

[7] Dumarcay, Jacques., dan Michael Smithies (translate) (1991), The Temples of Java, Singapore, Oxford University Press.

[8] Herwindo, Rahadhian P (2018) Eksistensi Candi: Sebagai Karya Agung Arsitektur Indonesia di Asia Tenggara, Yogyakarta, Kanisius.

[9] Dhar, parul pandya (2018) "Monuments, Motifs, Myths: Architecture and its Transformations in Early India and Southeast Asia", Cultural and Civilisational Links Between India and Southeast Asia: historical \& contemporary dimensions, Palgrave Macmillan. ISBN 9789811073168

[10] Frampton, Kenneth (1995) Studies in Tectonic Culture, The Poetics of Construction in Nineteenth and Twentieth Century Architecture, The MIT Press.

[11] Herwindo, Rahadhian P (1999) Kajian Tipo-Morfologi Arsitektur Candi di Jawa, ITB.

[12] Sukada, Budi, (1989), "Memahami Arsitektur Tradisional dengan pendekatan Tipologi", dalam Eko Budiarjo, Memahami Jatidiri Arsitektur Indonesia, Bandung, Alumni

[13] Herwindo, Rahadhian P (2016) "The Genealogy of the Architectural Shape of Minaret-Shaped Temples (Candi) in Indonesia", International Journal of Academic Research vol. 8 no. 5 September issue, IJAR. ISSN 2348-7666

[14] Soekmono, (1973) The Javanese Candi, Function and Meaning, Studies in Asian Art and Archaeology Vol. XVII, EJ Brill. ISBN 9004102159

[15] Acharya, prasanna kumar (1993) Manasara Series Vol IV, Oxford University Press.

[16] Oijevaar, k j (2007) The South Indian Hindu Temple Building Design System: On the architecture of the Silpa Sastra and the Dravida style, Delft University of Technology 
[17] Kramrisch, stella (1976) The Hindu Temple, Motilal Banarsidass. ISBN 9788120802223

[18] Chakrabarti, vibhuti (1998) Indian Architectural Theory, Curzon Press. ISBN 0700711139

[19] Hardy, adam (2009) Dravida Temples in the Samarān gaṇ asūtradhāra. South Asian Studies.

[20] Cruickshank, Dan (1996), Sir Banister Fletcher's : A History of Architecture Twentieth Edition, Oxford, Architectural Press.

[21] Encyclopedia of Indian temple architecture. Vol. I: South India (1983) New Delhi : America Institute of Indian Studies ; Philadelphia : University of Pennsylvania Press

[22] Atmadi, parmono (1988) Some Architectural Design Principles of Temples in Java: A Study Through the Buildings Projection on the Reliefs of Borobudur Temple, Gadjah Mada University Press. ISBN 9794200859

[23] Tjahjono, Gunawan, editor (2009), Sejarah Kebudayaan Indoneesia, Arsitektur, Jakarta, Raja.

[24] Rodriques, Nicholas L (2019), Komparasi Bentuk dan Tektonika Candi Hindu era Klasik Tua di Jawa dengan Kuil Hindu era Pallava di India Selatan, Skripsi Arsitektur, Universitas Katolik Parahyangan. 